\title{
Observations on the distribution, population structure and biology of Bathypterois mediterraneus Bauchot, 1962 in three areas of the Mediterranean Sea*
}

\author{
GIANFRANCO D’ONGHIA ${ }^{1}$, DOMINGO LLORIS ${ }^{2}$, LETIZIA SION ${ }^{1}$, \\ FRANCESCA CAPEZZUTO ${ }^{1}$ and MARY LABROPOULOU ${ }^{3}$ \\ 'Dipartimento di Zoologia, Università degli Studi, Via E. Orabona 4, 70125 Bari, Italy. \\ E-mail: g.donghia@biologia.uniba.it \\ ${ }_{2}^{2}$ Institut de Ciències del Mar (CSIC). Passeig Marítim de la Barceloneta 37-49, 08039 Barcelona, Spain. \\ ${ }^{3}$ Institute of Marine Biological Resources, Hellenic Centre for Marine Research, Agios Kosmas, 16604 Helliniko, Greece.
}

\begin{abstract}
SUMMARY: During the DESEAS cruise Bathypterois mediterraneus specimens were sampled in the Balearic Sea between 1000 and $2800 \mathrm{~m}$ as well as in the western and eastern Ionian Sea from 800 to $3300 \mathrm{~m}$ and from 800 to $2600 \mathrm{~m}$ respectively. The species was found to be more abundant at depths of 1500-2000 m. The size-range was $26-190 \mathrm{~mm}$ and the most abundant size class was around 100-120 mm standard length. No significant size-depth trends were shown for either length or weight. Negative allometry was shown in the growth of fishes and otoliths and in the relationship between fish length and otolith size in the samples from the western and eastern Ionian Sea. In these two areas the absolute growth was estimated by adopting the Von Bertalanffy function (western Ionian: $\mathrm{SL}_{\infty}=194.3 \pm 38.51 \mathrm{~mm}, \mathrm{k}=0.146 \pm 0.061 /$ year, $\mathrm{t}_{0}=-0.921 \pm 0.699$, $\phi^{\prime}=3.74$; eastern Ionian: $\mathrm{SL}_{\infty}=180.23 \pm 63.36 \mathrm{~mm}, \mathrm{k}=0.150 \pm 0.112 /$ year, $\left.\mathrm{t}_{0}=-0.968 \pm 0.868, \phi^{\prime}=3.70\right)$. Although most of the specimens were immature, some ripe gonads were recorded in individuals greater than $104 \mathrm{~mm}$ in standard length, confirming the simultaneous hermaphroditism in this fish. The results are discussed in relation to previous observations on the life strategy of $B$. mediterraneus in the Mediterranean Sea.
\end{abstract}

Key words: Bathypterois mediterraneus, distribution, population structure, growth, reproduction, Mediterranean Sea.

RESUMEN: OBSERVACIONES SOBRE LA DISTRIBUCIÓN, ESTRUCTURA DE LA POBLACIÓN Y BIOLOGÍA DE BATHYPTEROIS MEDITERRANEUS BAUCHOt, 1962 EN TRES ÁREAS DEL MAR MEDITERRÁNEO. - Durante la campaña DESEAS se obtuvieron especímenes de Bathypterois mediterraneus en el mar Balear entre 1000 y $2800 \mathrm{~m}$ así como en el mar Iónico occidental y oriental entre 800 y 3300 y entre 800 y 2600 m, respectivamente. La mayor abundancia de esta especie se encontró a profundidades comprendidas entre 1500 y $2000 \mathrm{~m}$. El rango de tallas encontrado abarcó entre 26 y $190 \mathrm{~mm}$ y la clase de talla de mayor abundancia fue 100 - $120 \mathrm{~mm}$ de longitud estandar. No se encontraron tendencias significativas que relacionaran la talla o el peso con la profundidad. Se encontró alometría negativa en el crecimiento de los ejemplares, en los otolitos y en la relación entre la longitud del pez y la talla del otolito en las muestras del mar Iónico. En estas dos áreas del Iónico, el crecimiento absoluto se estimó por medio de la función de von Bertalanffy (Iónico occidental: $\mathrm{SL}_{\infty}=194.3 \pm 38.51 \mathrm{~mm}, \mathrm{k}=0.146 \pm 0.061 / \mathrm{año}$, $\mathrm{t}_{0}=-0.921 \pm 0.699, \phi ’ 03.74 ;$ Iónico oriental, $\mathrm{SL}_{\infty}=180.23 \pm 63.36 \mathrm{~mm}, \mathrm{k}=0.150 \pm 0.112 / \mathrm{año}, \mathrm{t}_{0}=-0.968 \pm 0.868, \phi ’=$ 3.70). A pesar de que la mayoría de especimenes fueron inmaduros, se registraron algunas gónadas ovadas en individuos superiores a $104 \mathrm{~mm}$ de longitud estandar, confirmando el hermafroditismo simultáneo en esta especie. Los resultados se discuten en función de observaciones previas realizadas sobre la estrategia vital de B. mediterraneus en el mar Mediterráneo.

Palabras clave: Bathypterois mediterraneus, distribución, estructura poblacional, crecimiento, reproducción, Mediterráneo.

*Received February 15, 2003. Accepted November 27, 2003. 


\section{INTRODUCTION}

The Mediterranean tripodfish Bathypterois mediterraneus Bauchot, 1962 is one of the deepest teleost fish of this basin, being found down to 2830 m (Geistdoerfer and Rannou, 1972). Its distribution throughout the Mediterranean has been known since the first finding in the Catalan Sea (Bauchot, 1962) to the more recent finding off the coast of Israel (Galil and Goren, 1994). Several findings of this fish have been recorded in both the western (Raimbault, 1963; Tortonese and Relini Orsi, 1970; Geistdoerfer and Rannou, 1972) and eastern basin (Papaconstantinou, 1988; Klausewitz, 1989; Galil and Goren, 1994; Kallianiotis et al., 2000). Its feeding ecology has been studied by Carrassón and Matallanas (1990, 1994, 2001), its growth by Morales-Nin (1990) and Morales-Nin et al. (1996), and its reproduction by Fishelson and Galil (2001).

Although $B$. mediterraneus is one of the two deep-sea teleost fish that are endemic to the Mediterranean Sea (Quignard and Tomasini, 2000), knowledge of its distribution and abundance throughout the basin is rather fragmentary. In fact, abundance, distributional pattern and population structure have only been studied down to about 2300 $\mathrm{m}$ in the western Mediterranean, where some deepsea investigations started in 1985 (Allué et al., 1984; Stefanescu et al., 1992a,b, 1993, 1994; Morales-Nin et al., 1996). In the eastern Mediterranean, apart from the work on the gonad structure and reproductive cycle by Fishelson and Galil (2001), data on this fish rank no higher than its occurrence and sizes of specimens collected (Klausewitz, 1989; Galil and Goren, 1994; Kallianiotis et al., 2000).

The opportunity for further research into the depth and geographic distribution of $B$. mediterraneus was provided by the DESEAS research project funded by the EU. Although the main objective of this research was to obtain information on the abundance of Aristeus antennatus as far as the maximum depth range of the species distribution in the Mediterranean, data were also collected on the other species associated in the catches. The main objective of this paper is to provide a contribution to the knowledge on the distribution and population structure of $B$. mediterraneus in three areas of the Mediterranean Sea: the Balearic Sea, and the western and eastern Ionian Sea. Growth and reproduction were also investigated in the population sampled in the two latter areas and the relevant results are reported here.

\section{MATERIALS AND METHODS}

The DESEAS deep-sea cruise was carried out in June 2001 in three areas of the Mediterranean Sea (Fig. 1). The Balearic area extends from $38^{\circ} 04^{\prime} 06^{\prime \prime} \mathrm{N} 1^{\circ} 44^{\prime} 18^{\prime \prime} \mathrm{E}$ to $40^{\circ} 48^{\prime} 18^{\prime \prime} \mathrm{N} 5^{\circ} 34^{\prime} 36^{\prime \prime} \mathrm{E}$, the western Ionian area extends from $35^{\circ} 41^{\prime} 04^{\prime \prime} \mathrm{N}$ $16^{\circ} 24^{\prime} 48^{\prime \prime} \mathrm{E}$ to $38^{\circ} 18^{\prime} 30^{\prime \prime} \mathrm{N} 17^{\circ} 47^{\prime} 00^{\prime \prime} \mathrm{E}$, and the eastern Ionian area extends from $36^{\circ} 19^{\prime} 31^{\prime \prime} \mathrm{N}$ $21^{\circ} 54^{\prime} 23^{\prime \prime} \mathrm{E}$ to $36^{\circ} 51^{\prime} 24^{\prime \prime} \mathrm{N} 22^{\circ} 14^{\prime} 54^{\prime \prime} \mathrm{E}$.

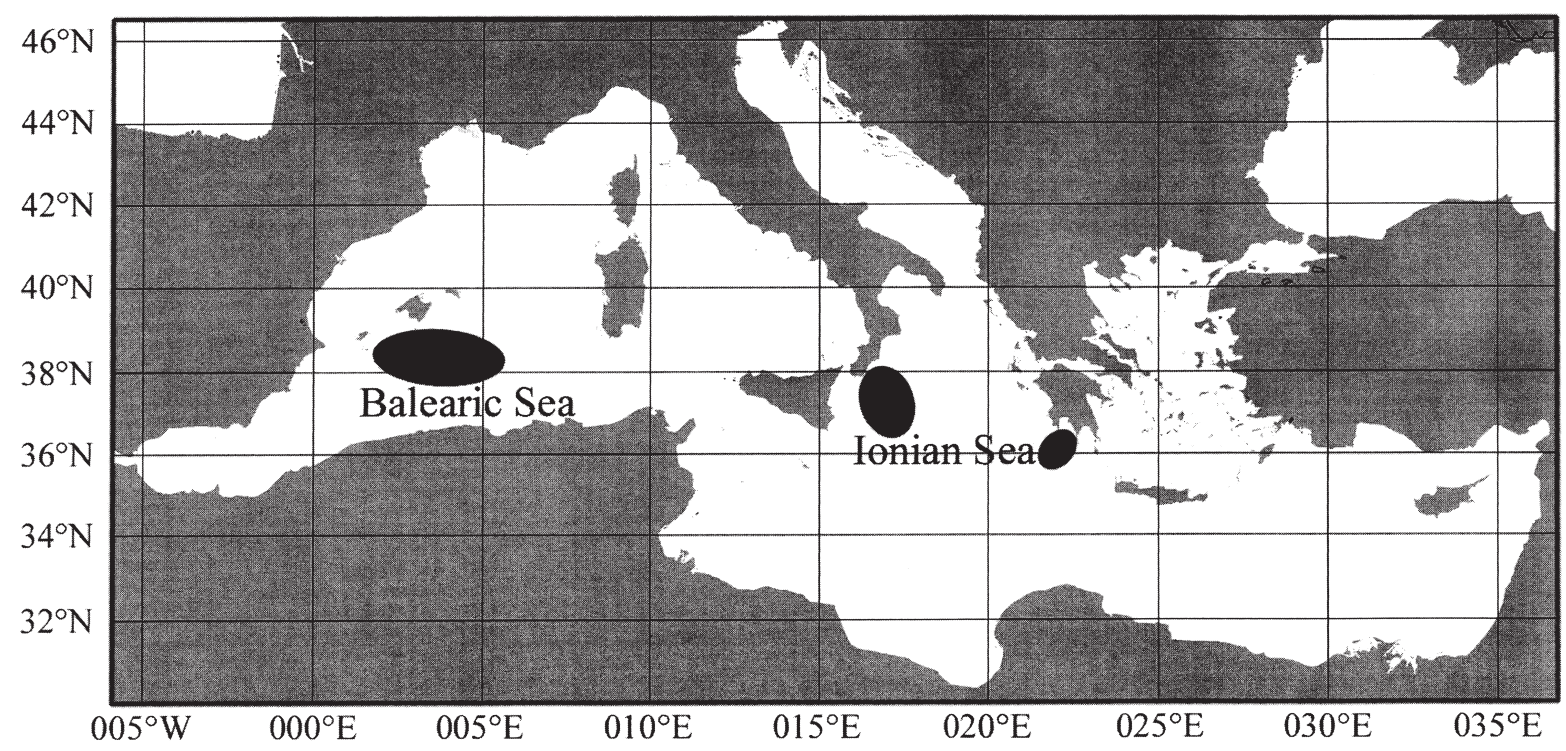

FIG. 1. - Map of the Mediterranean Sea with indication of the study areas during the DESEAS survey. 
TABLE 1. - Number of hauls by depth carried out in the three study areas during the DESEAS survey.

\begin{tabular}{lccc}
\hline Depth $(\mathrm{m})$ & Balearic area & $\begin{array}{c}\text { Western } \\
\text { Ionian area }\end{array}$ & $\begin{array}{c}\text { Eastern } \\
\text { Ionian area }\end{array}$ \\
\hline 600 & 1 & 1 & 2 \\
650 & 1 & 1 & 2 \\
800 & 1 & 1 & \\
802 & 1 & 1 & 1 \\
11000 & 1 & 2 & 1 \\
1200 & & 1 & 1 \\
1300 & 1 & 1 & 1 \\
1700 & 1 & & \\
2000 & & & \\
2200 & & 1 & 9 \\
2600 & & 1 & \\
2800 & 7 & 10 & \\
4000 & & & \\
Total hauls & & & \\
\hline
\end{tabular}

The sampling was conducted with the otter trawl Maireta System (OTMS) using the R/V García del Cid (38 m long; 1500 HP). The OTMS (height 1.8$2 \mathrm{~m}$; horizontal opening $14 \mathrm{~m}$ ) was trawled by a single warp and operated with a pair of rectangular iron otter boards $(1.20 \times 2.0 \mathrm{~m} ; 450 \mathrm{~kg})$. A detailed description of the net can be found in Sardà et al. (1998). The initial and final tow times and the net opening were measured by means of the SCANMAR sonar system. The vessel speed and geographical position were measured using differential GPS. The trawling was carried out during daylight hours. The number of hauls carried out in each area, with the indication of the depth, is reported in Table 1.

Haul duration ranged from 1 to 3 hours, but was standardised to $\mathrm{km}^{2}$. Standard Length (SL) was measured to the nearest $\mathrm{mm}$ and weight to the nearest $0.1 \mathrm{~g}$. Most $B$. mediterraneus specimens were measured and weighed on board due to the limited space in the refrigerators. Considering that the main knowledge on this fish comes from the western Mediterranean, samples of specimens collected in the western and eastern Ionian Sea were brought to the laboratory where otoliths were taken and gonads were examined.

The average density $\left(\mathrm{N} \mathrm{km}^{-2}\right)$ and the length-frequency distributions (10 $\mathrm{mm}$ SL size classes) by depth and area were computed. The Mann-Whitney U-test (Conover, 1980) was employed in order to detect significant variations between the density values recorded in the 1500-2000 m depth stratum and those in shallower $(\leq 1300 \mathrm{~m})$ and deeper $(\geq 2000$ m) strata. The size distributions between the three areas were compared using the Percentage of Similarity (Kohn and Riggs, 1982). The significance of the differences was determined by the Kolmogoroff-Smirnov test (Möller, 1979). Sizeweight relationship was computed according to the power curve function log-transformed $(\ln \mathrm{W}=\ln$ a $+\mathrm{b} \ln \mathrm{SL}$ ) for specimens collected in the western and eastern Ionian Sea. Differences between these two areas were determined using the Chow-test (Koutsoyiannis, 1977). This test determines whether there is a significant difference between the slope (b) and the intersect (a) of the regression lines estimated from different samples. The changes in size (both SL and weight) with depth were statistically tested by means of regression analysis, considering the population sampled in all three areas. The coefficient of determination $\left(\mathrm{r}^{2}\right)$ was also calculated to determine what proportion of the variance of size could be attributed to change in depth (Stefanescu et al., 1992b).

Both sagittae were removed from 110 and 64 specimens collected in the western and eastern Ionian respectively. Otoliths were placed in a black dish with glycerin $(30 \%)$ and alcohol $(70 \%)$ to improve reading. An opaque and translucent zone deposition pattern was considered as an annual event (Morales-Nin et al., 1996). Otoliths were read on the major axis of the proximal surface (longitudinal plane) at least twice independently by two observers. If agreement was not reached, the otoliths in question were excluded from the growth estimations. The number of annual rings was conventionally designated with $1,2,3,4, \ldots \ldots . ., \mathrm{n}$. The Von Bertalanffy function was fitted to the age-length keys obtained. The growth performance index $\left(\phi^{\prime}\right)$ (Munro and Pauly, 1983) was computed $\left(\phi^{\prime}=\log \mathrm{k}\right.$ $+2 \log \mathrm{L}$ ) in order to compare growth rates between study areas.

The maturity stage of the gonad (ovotestis) was recorded macroscopically from 208 individuals sampled in the Ionian Sea. According to Fishelson and Galil (2001), morphology, thickness and colour of the gonad were considered in three main maturity stages: I) immature, the gonad consists of two thin colourless parallel filaments; II) maturing, the gonad appears to be $2-3 \mathrm{~mm}$ thick, pink in colour with small eggs only visible using the stereoscope; III) mature, the gonad appears to be thicker and longer, orange in colour with evident eggs. In this stage, the testicular part was barely evident under the stereoscope. In order to confirm macroscopic observations in maturing and mature specimens, his- 
TABLE 2. - Abundance $\left(\mathrm{N} \mathrm{km}^{-2}\right)$ by depth of Bathypterois mediterraneus caught in the three study areas during the DESEAS survey.

\begin{tabular}{lccc}
\hline Depth (m) & $\begin{array}{c}\text { Balearic area } \\
\text { Western Ionian } \\
\text { area }\end{array}$ & $\begin{array}{c}\text { Eastern Ionian } \\
\text { area }\end{array}$ \\
\hline 600 & & & \\
650 & & 18.63 & $26.00^{*}$ \\
800 & & 57.04 & \\
802 & 10.85 & 149.79 & 159.14 \\
1000 & & $1281.45^{*}$ & 169.22 \\
1100 & & 809.20 & 777.88 \\
1200 & 266.59 & 313.07 & 223.24 \\
1300 & & & 119.35 \\
1500 & & & \\
2000 & 171.94 & & \\
2200 & 191.65 & 22.22 & 7 \\
2500 & & & \\
2800 & & 8 & \\
3300 & 4 & & \\
4000 & & & \\
Total hauls & & & \\
\hline
\end{tabular}

* Mean value of two hauls

tological analysis was carried out on a subsample of gonads (10) removed from individuals greater than $70 \mathrm{~mm}$ SL. The gonads were fixed in Bouin's solution. They were then dehydrated in an ascending ethanol series and embedded in paraffin wax (melting point $=56^{\circ} \mathrm{C}$ ). Serial sections $7 \mu \mathrm{m}$ thick were cut and stained with Mayer's hematoxylin-eosin.

\section{RESULTS}

\section{Distribution}

B. mediterraneus was collected between 1000 and $2800 \mathrm{~m}$ off the southern Balearic Islands, between 800 and $3300 \mathrm{~m}$ in the western Ionian Sea and between 800 and $2600 \mathrm{~m}$ in the eastern Ionian Sea. Although marked abundance fluctuations were recorded across the investigated depth range in each area (Table 2), the highest density values were computed at depths of 1500-2000 m (Fig. 2). Significant differences were shown both between density values in this depth stratum and shallower depths $(\leq 1300$ $\mathrm{m})(\mathrm{P}<0.01)$ and between density values in the 1500-2000 m depth stratum and those observed at depths greater than $2000 \mathrm{~m}(\mathrm{P}<0.05)$.

\section{Population structure}

The length-frequency distributions of the specimens sampled in each area are shown in Figure 3. The specimens caught in the Balearic Sea measured

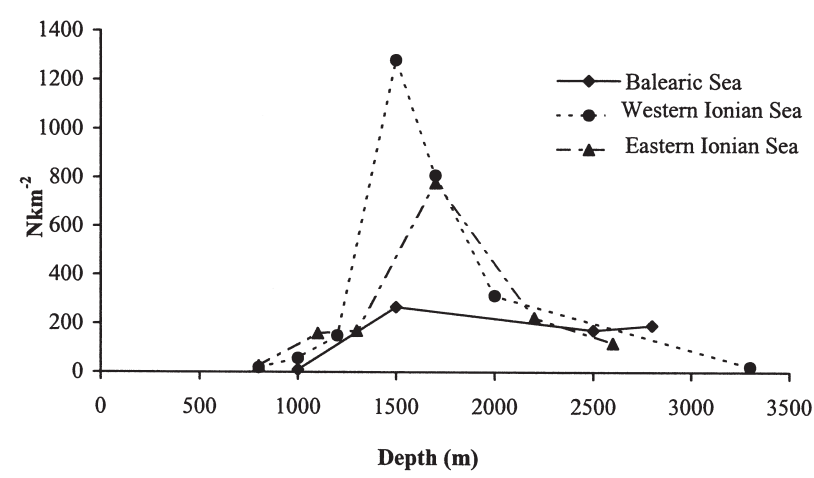

FIG. 2. - Relationship between depth (m) and abundance $\left(\mathrm{N} \mathrm{km}^{-2}\right)$ of $B$. mediterraneus in each study area.
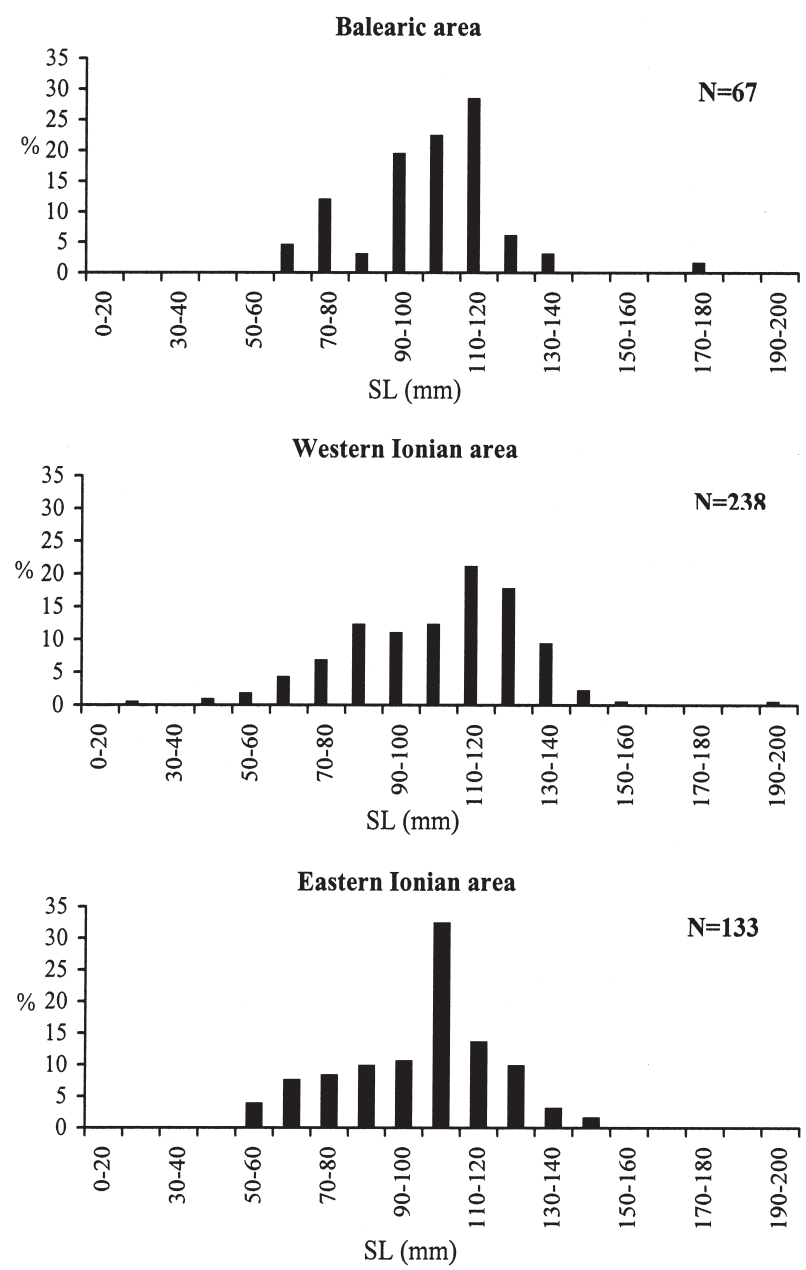

FIG. 3. - Size-frequency distributions of B. mediterraneus collected in the three study areas during the DESEAS survey. $\mathrm{N}$, number of individuals.

between 60 and $170 \mathrm{~mm} \mathrm{SL}$. The size-range was 26$190 \mathrm{~mm} \mathrm{SL}$ in the western Ionian and 50-143 mm $\mathrm{SL}$ in the eastern Ionian. The most abundant size class was $110-120 \mathrm{~mm}$ SL in the former two areas and $100-110 \mathrm{~mm}$ SL in the latter. A positive asymmetry was evident in the size distribution of each study area. Though high similarity percentages were 
TABLE 3. - Similarity coefficient matrix for the size-frequency distributions of Bathypterois mediterraneus.

\begin{tabular}{|c|c|c|c|}
\hline \multicolumn{2}{|c|}{ Balearic area } & \multirow{2}{*}{$\begin{array}{l}\text { Western Ionian } \\
\text { area }\end{array}$} & \multirow{2}{*}{$\begin{array}{l}\text { Eastern Ionian } \\
\text { area }\end{array}$} \\
\hline Balearic area & 1 & & \\
\hline Western Ionian area & 0.67 & 1 & \\
\hline Eastern Ionian area & 0.71 & 0.73 & 1 \\
\hline
\end{tabular}
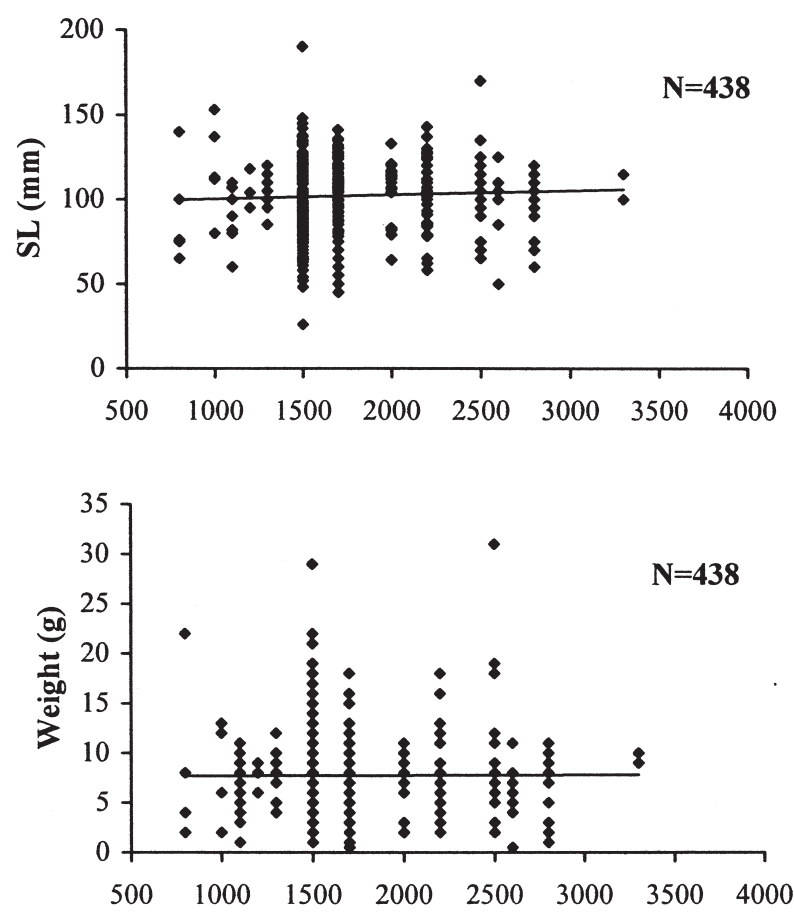

Depth (m)

FIG. 4. - Relationship of length (above) and weight (bottom) vs depth, calculated by regression analysis in $B$. mediterraneus $(\mathrm{SL}=$ 0.0024 depth $+97.98 ; \mathrm{r}^{2}=0.002 ;$ n.s; Weight $=0.00004$ depth + $\left.7.66 ; r^{2}=0.00002 ; n . s.\right)$. N, number of individuals.

found between the size polygons of the three areas (Table 3), significant differences were provided by the Kolmogoroff-Smirnov test (between western and eastern Ionian area $\mathrm{D}=22.6, \mathrm{P}<0.01$; between Balearic and western Ionian area $\mathrm{D}=18.96, \mathrm{P}<$ 0.01 ; between eastern Ionian and Balearic area $\mathrm{D}=$ 10.99, $\mathrm{p}<0.01)$.

No significant size-depth variations were shown for either length or weight of the specimens collected from 800 down to $3300 \mathrm{~m}$ (Fig. 4).

\section{Age and growth}

The size-weight relationship parameters estimated for the population sampled in the western and eastern Ionian Sea are reported in Table 4. The
TABLE 4. - Parameters of the relationship between standard length $(\mathrm{mm})$ and weight $(\mathrm{g})$ computed for Bathypterois mediterraneus from the western and eastern Ionian Sea. N, number of individuals.

\begin{tabular}{lcccc}
\hline & $\mathrm{N}$ & $\mathrm{a}$ & $\mathrm{b}$ & $\mathrm{r}^{2}$ \\
\hline Western Ionian Sea & 233 & $1.5 \mathrm{E}-05$ & 2.814 & 0.93 \\
Eastern Ionian Sea & 130 & $1.4 \mathrm{E}-05$ & 2.818 & 0.92 \\
\hline
\end{tabular}

TABLE 5. - Parameters of the relationship between otolith diameter $(\mathrm{mm})$ and otolith weight $(\mathrm{g})$ computed for Bathypterois mediterraneus from the western and eastern Ionian Sea. N, number of individuals.

\begin{tabular}{lcccc}
\hline & $\mathrm{N}$ & $\mathrm{a}$ & $\mathrm{b}$ & $\mathrm{r}^{2}$ \\
\hline Western Ionian Sea & 81 & $1.64 \mathrm{E}-04$ & 2.671 & 0.86 \\
Eastern Ionian Sea & 60 & 2E-04 & 2.382 & 0.81 \\
\hline
\end{tabular}

TABle 6. - Parameters of the relationship between fish standard length $(\mathrm{mm})$ and otolith diameter $(\mathrm{mm})$ computed for Bathypterois mediterraneus from the western and eastern Ionian Sea. N, number of individuals.

\begin{tabular}{lrccc}
\hline & $\mathrm{N}$ & $\mathrm{a}$ & $\mathrm{b}$ & $\mathrm{r}^{2}$ \\
\hline Western Ionian Sea & 117 & 0.0519 & 0.8419 & 0.92 \\
Eastern Ionian Sea & 74 & 0.0522 & 0.8449 & 0.94 \\
\hline
\end{tabular}

results of the Chow test revealed no significant differences between the two sides of the Ionian Sea (F $=0.56, \mathrm{P}>0.05)$. The allometric coefficient $(\mathrm{b})$ was significantly smaller than 3 in both cases $(\mathrm{P}<0.01)$.

Otoliths of $B$. mediterraneus show distinct opaque and translucent rings around an opaque nucleus, corresponding to fast and slow growth phases (William and Bedford, 1974). The diameter-weight relationship computed for otoliths showed a negative allometry without significant differences between the western and eastern Ionian Sea $(F=2.19, \mathrm{P}>0.05)$ (Table 5). The relationship between fish standard length and otolith diameter revealed a relative decrease in otolith size with fish length with no significant differences between the two sides of the Ionian sea $(\mathrm{F}=$ 2.26, P > 0.05) (Table 6).

The age-length keys obtained for the specimens sampled in the western and eastern Ionian Sea are shown in Table $7 \mathrm{a}$ and $7 \mathrm{~b}$ respectively. An asymptotic pattern of growth for both areas was observed. Von Bertalanffy growth parameters, growth performance index ( $\left.\phi^{\prime}\right)$ and maximum age found in the sampled population are reported in Table 8 . Though different VBGF parameters were estimated in the western and eastern Ionian, the same growth pattern was shown in the two areas. 
TABLE 7. - Age-length key of Bathypterois mediterraneus caught in the Western Ionian and in the Eastern Ionian Sea. N, number of individuals; SL, standard length; S.D., standard deviation.

\begin{tabular}{lllllrlll}
\hline $\mathrm{SL}(\mathrm{mm})$ & & & & \multicolumn{1}{c}{ Age } & & & \\
& 1 & 2 & 3 & 4 & 5 & 6 & 7 & 8 \\
\hline
\end{tabular}

Western Ionian Sea

\begin{tabular}{|c|c|c|c|c|c|c|c|c|}
\hline $40-50$ & 1 & & & & & & & \\
\hline $50-60$ & 2 & 3 & & & & & & \\
\hline $60-70$ & & 9 & & & & & & \\
\hline $70-80$ & & & 3 & 4 & & & & \\
\hline $80-90$ & & & 4 & 9 & 1 & & & \\
\hline $90-100$ & & & & 4 & 6 & & & \\
\hline $100-110$ & & & & 7 & 4 & 1 & & \\
\hline $110-120$ & & & & 1 & 13 & 1 & & \\
\hline $120-130$ & & & & 2 & 7 & 9 & & \\
\hline $130-140$ & & & & & 3 & 9 & 5 & 1 \\
\hline $140-150$ & & & & & & & & 1 \\
\hline $\mathrm{N}$ & 3 & 12 & 7 & 27 & 34 & 20 & 5 & 2 \\
\hline Mean & 52.0 & 61.3 & 79.6 & 104.5 & 113.0 & 126.7 & 133.6 & 138.0 \\
\hline S.D. & 5.29 & 5.26 & 6.68 & 14.66 & 12.51 & $1 \quad 8.80$ & 3.05 & 4. \\
\hline
\end{tabular}

Eastern Ionian Sea

$\begin{array}{lccccccccc}40-50 & & & & & & & \\ 50-60 & 1 & 3 & & & & & \\ 60-70 & & 3 & 2 & & & & \\ 70-80 & & & 4 & 1 & & & \\ 80-90 & & 1 & 2 & 1 & & & & \\ 90-100 & & & 1 & 5 & & & & \\ 100-110 & & & & 7 & 5 & 1 & & \\ 110-120 & & & & 6 & 6 & 2 & & \\ 120-130 & & & & 2 & 4 & 2 & 2 & \\ 130-140 & & & & & 2 & & 1 & \\ 140-150 & & & & & & & & \\ \text { N } & 1 & 7 & 9 & 22 & 17 & 5 & 3 & - \\ \text { Mean } & 50.0 & 62.6 & 75.0 & 102.7 & 114.1 & 113.4 & 126.7 & - \\ \text { S.D. } & - & 8.73 & 9.35 & 12.02 & 10.51 & 6.50 & 5.31 & - \\ & & & & & & & & & \\ \end{array}$

\section{Maturity}

Half of the specimens examined macroscopically were immature (48\%), $31 \%$ were maturing and $22 \%$ were mature (Table 9). Histological analysis generally confirmed macroscopic observations. Maturing gonads were observed in specimens greater than 100 $\mathrm{mm}$ SL. Spermatocytes and spermatids were shown in the testis; previtellogenic ovocytes $(60-80 \mu \mathrm{m})$ and larger ovocytes in early vitellogenic phase with evident nuclei (300-320 $\mu \mathrm{m}$ ) were observed in the ovary.

Mature gonads were shown in individuals of sizes between 104 and $138 \mathrm{~mm} \mathrm{SL}$. In the same
TABLE 9. - Number of B. mediterraneus of different maturity stages in different sizes. SL, standard length.

\begin{tabular}{lccc}
\hline SL $(\mathrm{mm})$ & $\begin{array}{c}\text { Immature } \\
\text { I }\end{array}$ & $\begin{array}{c}\text { Maturing } \\
\text { II }\end{array}$ & $\begin{array}{c}\text { Mature } \\
\text { III }\end{array}$ \\
\hline$>70$ & 21 & & \\
$70-100$ & 40 & 4 & \\
$100-120$ & 29 & 30 & 15 \\
$120-140$ & 9 & 26 & 30 \\
$>140$ & & 4 & \\
\hline
\end{tabular}

gonad cysts with spermatids and spermatozoa were observed in the testis, and hydrated ovocytes between 320-450 $\mu \mathrm{m}$ in size were shown in the ovary, confirming the simultaneous hermaphroditism in this fish (Fishelson and Galil, 2001).

\section{DISCUSSION}

The results reported in this study show that $B$. mediterraneus is a species with a wide depth distribution throughout the Mediterranean Sea. It was found in 19 of the 21 hauls carried out from 800 to $3300 \mathrm{~m}$. The latter is the greatest depth at which the species has been collected.

The highest densities were shown between 1500 and $2000 \mathrm{~m}$. This is partially in agreement with previous deep-sea studies carried out in the Catalan Sea, where the abundance of this fish exhibited a proportional increase with depth down to $2251 \mathrm{~m}$ (Stefanescu et al., 1993; Morales-Nin et al., 1996). However, the small number of hauls carried out during the DESEAS survey and the decreasing efficacy of the sampling with depth prevent us from drawing definitive conclusions about the depths of the greatest density of this fish. The sampling design during this study was not completely satisfactory due to the different bathymetry and topography of the three areas. Many zones, mostly at depths greater than $1500 \mathrm{~m}$, prevented trawling or caused the breaking of the net due to irregular bottoms resulting in the unbalanced number of hauls between the three areas, mostly below the abovementioned depth.

TABle 8. - Parameters of the Von Bertalanffy growth equation ( \pm S.E.) fitted to standard length (SL) at age for B. mediterraneus from the Western and Eastern Ionian Sea, and from pooled data.

\begin{tabular}{lccc}
\hline & Western Ionian & Eastern Ionian & Western and Eastern Ionian \\
\hline $\mathrm{SL} \infty(\mathrm{mm})$ & $194.30 \pm 38.51$ & $180.23 \pm 63.36$ & $196.71 \pm 42.05$ \\
$\mathrm{~K}($ year $)$ & $0.146 \pm 0.061$ & $0.150 \pm 0.112$ & $0.139 \pm 0.061$ \\
$\mathrm{t}_{0}$ & $-0.921 \pm 0.699$ & $-0.968 \pm 0.868$ & $-0.981 \pm 0.568$ \\
$\phi^{\prime}$ & 3.74 & 3.70 & 3.73 \\
Max age & 8 & 7 & 8 \\
\hline
\end{tabular}


Despite these difficulties, the high densities shown below $1500 \mathrm{~m}$ highlight the adaptation of $B$. mediterraneus to the food-scarce environment of the deep Mediterranean (Carrassón and Matallanas, 2001). In fact, the vertical ichthyofauna zonation shown in this basin around depths of 1200-1400 m has been attributed to the trophic resources available above and below this bathymetry linked to the distribution of mesopelagic organisms (Carrassón and Matallanas, 1990; Stefanescu et al., 1992b, 1993; Morales-Nin et al., 1996; Moranta et al., 1998; Maynou and Cartes, 2000). According to such a zonation, larger species with high energy requirements, such as Alepocephalus rostratus, Trachyrhynchus trachyrhynchus and Mora moro, are replaced at greater depths by smaller species which utilise a broad spectrum of benthopelagic prey, such as $B$. mediterraneus, Chalinura mediterranea and Coryphaenoides guentheri. Although $B$. mediterraneus feeds mostly on benthopelagic calanoid copepods, it also tends to diversify its diet with increasing depth, feeding on both epibenthic and endobenthic resources (Carrassón and Matallanas, 2001). Studies on deep-sea fauna carried out in the western and eastern Mediterranean using traps at depths between 1845 and $4505 \mathrm{~m}$ have revealed a high presence of decapods, mysids and amphipods (Della Croce and Albertelli, 1995). The euryphagic increase with depth in $B$. mediterraneus enables it to be widely distributed in the food-limited environment of the Mediterranean Sea. Indeed, a striking dominance of $B$. mediterraneus has been shown at depths greater than $1400 \mathrm{~m}$ in the western Mediterranean (Stefanescu et al., 1993; Moranta et al., 1998). Furthermore, Bathypterois species are among the dominant components of the abyssal fauna of oligotrophic regions (Merrett, 1987).

According to previous observations in the western Mediterranean (Rannou and Gaborit-Rezzouk, 1976; Stefanescu et al., 1992b; Morales-Nin et al., 1996), no depth-size trend was shown, indicating a wide vertical distribution of the specimens irrespective of size and age. In this respect, Carrassón and Matallanas (2001) reported that ontogenetic differences in the diet are small in this fish.

The size structure pattern was comparable between the three areas and with that reported by Morales-Nin et al. (1996) for the Catalan Sea, though in the latter the most abundant size component was that of $130-150 \mathrm{~mm}$. These authors reported that the absence of progression of cohorts over time might be due to continuous breeding. Recently,
Fishelson and Galil (2001) reported that B. mediterraneus spawns synchronously during autumn, from September to November. However, the occurrence of some mature specimens recorded during this study, confirming the simultaneous hermaphroditism in this fish, would indicate that its spawning period might be more prolonged. In this regard, Tortonese and Relini Orsi (1970) observed a mature ovotestis in a specimen caught in the Ligurian Sea during April.

According to Morales-Nin et al. (1996) a negative allometry was shown in the growth of fishes and otoliths and in the relationship between fish length and otolith size. A low growth rate was detected in the sampled individuals. The growth pattern was the same on the two sides of the Ionian Sea and overlapped that observed in the Catalan Sea (MoralesNin et al., 1996). The small number of individuals greater than $140 \mathrm{~mm}$ and the difficulties in distinguishing the zones in the otolith margin prevented us from obtaining an age-length key for individuals older than 8 years.

In our opinion, the low growth rate together with a prolonged reproductive season would mask the presence of any modal components in the population. However, it remains unclear why the most abundant specimens in the sampled population were those of 130-150 mm in the Catalan Sea (MoralesNin et al., 1996) and 100-120 mm in the present study. Most probably, a greater number of larger individuals were caught in the Catalan Sea using the OTSB trawl. Unfortunately, Morales-Nin et al. (1996) did not report differences in the size composition between the capture of OTSB trawl and that of OTMS. We agree with these authors that the smaller specimens would be less vulnerable to the gears used since they might not be completely recruited to the bottom. Furthermore, specimens greater than $150 \mathrm{~mm}$ are less frequent in the samples since they become rare in the population.

Finally, the same patterns shown in the fish and otolith growth in the two areas of the Ionian Sea, coupled with the closeness of these two areas, would suggest the occurrence of individuals belonging to the same population in the samples collected in this Mediterranean basin.

\section{ACKNOWLEDGEMENTS}

This work was supported by the Directorate General of Fisheries of the European Commission as 
part of the DESEAS project (Exploratory survey to collect data of the exploited and virgin stocks of deep-sea shrimp A. antennatus, of interest to the CFP).

\section{REFERENCES}

Allué, C., J.A. Rucabado, D. Lloris and R. Allué. - 1984. Contribución al conocimiento de la ictiofauna abisal del Mediterráneo español. Bull. Soc. Catal. Ictiol. Herpetol., 10: 8-13.

Bauchot, M.-L. - 1962. Description d'un nouveau Bathypterois méditerranéen. Vie Milieu, 13(4): 613-647.

Carrassón, M. and J. Matallanas. - 1990. Preliminary data about the feeding habits of some deep-sea Mediterranean fishes. J. Fish Biol., 36: 461-463.

Carrassón, M. and J. Matallanas. - 1994. Morphometric characteristics of the alimentary tract of deep-sea Mediterranean teleosts in relation to their feeding habits. Mar. Biol., 118: 319-322.

Carrassón, M. and J. Matallanas. - 2001. Feeding ecology of the Mediterranean spiderfish, Bathypterois mediterraneus (Pisces: Chlorophthalmidae), on the western Mediterranean slope. Fish. Bull., 99: 266-274.

Conover, W.J. - 1980. Practical nonparametric statistics. Wiley and Sons, New York.

Della Croce, N. and G. Albertelli. - 1995. Organismi batiali mediterranei: ricchezza o povertà. Biol. Mar. Medit., 2(2): 171175.

Fishelson, L. and B.S. Galil. - 2001. Gonad Structure and Reproductive Cycle in the Deep-Sea Hermaphrodite Tripodfish, Bathypterois mediterraneus (Chlorophthalmidae, Teleostei). Copeia, 2: 556-560.

Galil, B.S. and M. Goren. - 1994. The deep sea Levantine fauna - new records and rare occurrences. Senckenberg. Marit, 25: 41-52.

Geistdoerfer, P. and M. Rannou. - 1972. Poissons benthiques récoltés en Méditerranée occidentale par le N.O. Jean Charcot (campagne Polymède). Bull. Mus. Natn. Hist. Nat., Paris, series 3, 25(19): 101-110.

Kallianiotis, A., K. Sophronidis, P. Vidoris and A. Tselepides. 2000. Demersal fish and megafaunal assemblages on the Cretan continental shelf and slope (NE Mediterranean): seasonal variation in species density, biomass and diversity. Prog. Oceanogr., 46: 429-455.

Klausewitz, W. - 1989. Deep-sea and deep water fish of the eastern Mediterranean, collected during the METEOR-Expedition 1987. Senckenberg. Marit., 20(5/6): 251-263.

Kohn, A.J. and A.C. Riggs. - 1982. Sample size and dependence in measures of proportional similarity. Mar. Ecol. Prog. Ser., 9: $147-151$.

Koutsoyiannis, A. - 1977. Theory of econometrics: an introductory exposition of econometric methods. Macmillan Press Ltd, Hong Kong.

Maynou, F. and J.E. Cartes. - 2000. Community structure of bathyal decapod crustaceans off south-west Balearic Islands (western Mediterranean): seasonality and regional patterns in zonation. J. Mar. Biol. Ass. UK, 80: 789-798.

Merrett, N.R. - 1987. A zone of faunal change in assemblages of abyssal demersal fish in the eastern north Atlantic: a response to seasonality in production? Biol. Oceanogr., 5: 137-151.

Möller, F. - 1979. Manual of methods in aquatic environment research. Part 5. Statistical tests. FAO Fish. Tech. Pap., 182: $131 \mathrm{pp}$.

Morales-Nin, B. - 1990. A first attempt at determining growth patterns of some Mediterranean deep-sea fishes. Sci. Mar., 54: 241-248.

Morales-Nin, B., E. Massutí and C. Stefanescu. - 1996. Bathymetric distribution and growth patterns of Bathypterois mediterraneus from the north-western Mediterranean Sea. $J$. Fish Biol., 49(Suppl. A): 276-288.

Moranta, J., C. Stefanescu, E. Massutí, B. Morales-Nin and D. Lloris. - 1998. Fish community structure and depth-related trends on the continental slope of the Balearic Islands (Algerian basin, western Mediterranean). Mar. Ecol. Prog. Ser., 171: 247 259

Munro, J.L. and D. Pauly. - 1983. A simple method for comparing growth of fishes and invertebrates. ICLARM Fishbyte, 1: 5-6.

Papaconstantinou, C. - 1988. Fauna Graeciae IV. Check-list of marine fishes of Greece. Hellenic Zoological Society, Athens.

Quignard, J.P. and J.A. Tomasini. - 2000. Mediterranean fish biodiversity. Biol. Mar. Medit., 7(3): 1-66.

Raimbault, R. - 1963. Notes sur certains espècies ichtyologiques capturées au cours des campagnes de l'Institut des Pêches en Méditerranée (1957-1961). Rév. Trav. Inst. Pêch. Marit., 27(1): 161-171.

Rannou, M. and M. Gaborit-Rezzouk. - 1976. Contribution à l'étude des Bathypteroidae (Pisces, Iniomi) de l'Atlantique et de la Méditerranée. Bull. Mus. Natn. Hist. Nat., Paris, series 3, 375, Zoologie 263: 453-466.

Sardà, F., J.E. Cartes, J.B. Company and A. Albiol. - 1998. A Modified Commercial Trawl Used to Sample Deep-Sea Megabenthos. Fish. Sci., 64(3): 492-493.

Stefanescu, C., D. Lloris and J. Rucabado. - 1992a. Deep-living demersal fishes in the Catalan Sea (western Mediterranean) below a depth of $1000 \mathrm{~m}$. J. Nat. Hist., 26: 197-213.

Stefanescu, C., D. Lloris and J. Rucabado. - 1993. Deep-sea fish assemblages in the Catalan Sea (western Mediterranean) below a depth of 1000 m. Deep-Sea Res., 40(4): 695-707.

Stefanescu, C., B. Morales-Nin and E. Massutí. - 1994. Fish assemblages on the slope in the Catalan Sea (Western Mediterranean): influence of a submarine canyon. J. Mar. Biol. Ass. UK, 74: 499-512.

Stefanescu, C., J. Rucabado and D. Lloris. - 1992b. Depth-size trends in western Mediterranean demersal deep-sea fishes. Mar. Ecol. Prog. Ser., 81: 205-213.

Tortonese, E. and L. Relini Orsi. - 1970. Osservazioni intorno a un Bathypterois (Pisces) catturato nel Golfo di Genova. Ann. Mus. St. Nat. Genova, 78: 181-188.

William, T. and B.C. Bedford. - 1974. The use of otoliths for age determination. In: T.B. Bagenal (ed.), The ageing of fish, pp. 114-123. Unwin Brothers, Old Woking, England. 